\title{
Increasing of IFN $\gamma$ Expression in Transformed Cells of Balb/c Mice Due to Ethanol Extract Cocoa Beans (Theobroma cacao)
}

\author{
Peningkatan Jumlah Ekspresi IFNy pada Mencit Balb/c yang Mengalami Transformasi Sel Akibat \\ Pemberian Ekstrak Etanol Biji Kakao (Theobroma cacao)
}

\author{
Iin Eliana Triwahyuni \\ Department of Oral Medicine, \\ Faculty of Dentistry, University of Jember \\ Jl. Kalimantan 37 Jember, \\ Email: eliana.triwahyuni@gmail.com
}

\begin{abstract}
As current technology cannot cure cancer completely, prevention becomes the main choice. To prevent the development of cell transformation into cancer cells, polyphenols that are widely found in cocoa beans (Theobroma cacao), is usable. IFN $\gamma$ plays an important role in immunity against cancer. This study aims to see the ability of cocoa beans ethanol extract to increase the number of IFN $\gamma$ expression in Balb/c mice undergoing cell transformation. This study used three groups Balb/c ( $n=4)$, namely K1 (normal control), K2 (negative control: injected with benzopyrene without ethanol extract of cocoa beans), and $\mathrm{K} 3$ (treatment: injected with benzopyrene, given $4 \mathrm{mg} / 30 \mathrm{gBW} / \mathrm{po} /$ day ethanol extract of cocoa beans). The mice were biopsied, and IFN $\gamma$ expression was examined by immune histochemical method. The results showed that IFN $\gamma$ expression increased significantly in K3. It can be concluded that ethanol extract of cocoa beans could increase IFN $\gamma$ expression in Balb/c mice undergoing cell transformation.
\end{abstract}

Keyword: IFN $\gamma$, cells transformation, Theobroma cacao

\begin{abstract}
Abstrak
Teknologi saat ini belum dapat menyembuhkan kanker secara tuntas, karena itu pencegahan menjadi pilihan utama. Untuk mencegah berkembangnya sel transformasi menjadi sel kanker, polifenol yang banyak terdapat pada biji kakao (Theobroma cacao), dapat digunakan. IFN $\gamma$ berperan penting dalam imunitas terhadap kanker. Penelitian ini bertujuan melihat kemampuan ekstrak etanol biji kakao dalam meningkatkan jumlah ekspresi IFN $\gamma$ pada mencit Balb/c yang mengalami transformasi sel. Penelitian ini menggunakan tiga kelompok mencit Balb/c ( $n=4)$ yaitu: K1 (kontrol normal), K2 (kontrol negatif: diinjeksi benzopyrene, tanpa diberi ekstrak etanol biji kakao), dan K3 (perlakuan: diinjeksi benzopyrene, diberi ekstrak etanol biji kakao $4 \mathrm{mg} / 30 \mathrm{gBB} / \mathrm{po} / \mathrm{hari}$ ). Kemudian mencit dibiopsi dan dilakukan pemeriksaan jumlah ekspresi IFN $\gamma$ dengan metode imuno histokimia. Hasil penelitian menunjukkan bahwa pada K3 terdapat peningkatan signifikan jumlah ekspresi IFN $\gamma$. Dapat disimpulkan bahwa ekstrak etanol biji kakao dapat meningkatkan ekspresi IFN $\gamma$ pada mencit Balb/c yang mengalami transformasi sel.
\end{abstract}

Keyword: IFN $\gamma$, transformasisel, Theobroma cacao

\section{INTRODUCTION}

One cause of death in the world is cancer. In Indonesia, cancer is the seventh leading cause of death $(5.7 \%){ }^{1}$ Of all cancers that occur in humans, head and neck cancer ranks 6th (3\%). Most (48\%) of head and neck cancers occur in the oral cavity, and $90 \%$ are squamous cell carcinoma of the oral cavity (SCC). ${ }^{2}$

Current technology is not able to cure cancer completely, while new cases continue to emerge. This causes the number of cancer patients including SCC continues to increase. Therefore, preventive measures are the first choice to prevent the rate of increase in the number of SCC patients.

Cancer prevention can be done at the stage of initiation, promotion, and cancer progression. ${ }^{3}$ The promotion phase transforms the transformed cells into cancer cells. This stage lasts for a long time, and some can experience regression. This provides an 
opportunity to inhibit or prevent the occurrence of SCC. Polyphenols can be used to prevent the development of the transformation and preneoplastic cells into cancer cells. ${ }^{4}$ Polyphenols are found in many cocoa beans (Theobroma cacao) which are widely produced in plantations spread almost throughout Indonesia. Indonesian people used to call cocoa plants as cocoa.

IFN $\gamma$ plays an important role in immunity against cancer. ${ }^{5}$ There has never been any research on the potential of ethanol extract of cocoa beans in increasing IFN $\gamma$ expression in Balb/c mice undergoing cell transformation.

Based on the description above, research is needed to determine the ability of ethanol extract of cocoa beans to increase the amount of IFN $\gamma$ expression in $\mathrm{Balb} / \mathrm{c}$ mice undergoing cell transformation. This study aimed to see the ability of ethanol extract of cocoa beans to increase the amount of IFN $\gamma$ expression in Balb/c mice undergoing cell transformation.

\section{MATERIALS AND METHOD}

This research was conducted at the Biochemical Laboratory and Electron Microscope Unit of the Faculty of Medicine, Airlangga University after being approved by the Ethics Commission of the Faculty of Dentistry, Airlangga University. This research was conducted with pure experiment with a completely random design. This research was an in vivo study using Balb/c mice models that have transformed. There were three groups in this study, namely K1 (normal control: without injection of benzopyrene, without ethanol extract of cocoa beans), K2 (negative control: injected with benzopyrene, without ethanol extract of cocoa beans), and K3 (treatment: injected with benzopyrene, given $4 \mathrm{mg} / 30 \mathrm{gBB}$ /PO/day ethanol extract of cocoa beans). Four repetitions were carried out in each group so that the total sample was 12 mice. Mice had the following criteria such as male, healthy, age \pm 2 months, and weight 20-30 grams. Previously, mice were adapted for one week, fed and drank ad libitum.

The animal model was made after being adapted for a week by exposing micewith0.08 mg benzopyrene/ $0.04 \mathrm{ml}$ of oleum olivarum in the oral cavity of the right buccal mucosa. The exposure was done by injection three times a week for three consecutive weeks. After that, it was left for two weeks.

The ethanol extract of cocoa beans was begun with the selection of cocoa pods, which were ripe cocoa pods from Forestero/Lindak types obtained from
Banjarsari Gardens, PTPN XII. After being picked and peeled, the cocoa beans were removed and cleaned. Then, it was dried by drying in the sun. The cocoa beans that have been dried were peeled and pollinated with a mesh particle size no. 25-35. A total of $3 \mathrm{~kg}$ of cocoa beans (Theobroma cacao), which have been pollinated were extracted by maceration with nhexane solvent. At first, the cocoa bean powder was put into a maceration container, then n-hexane was added until the entire sample was submerged. The container was tightly closed and left for one day while stirring several times. The mixture was filtered and remastered by adding n-hexane to the pulp. The extraction process was carried out until the color of the solvent was clear. From this process, the low-fat cocoa pulp was produced. Furthermore, the extraction of polyphenols with $80 \%$ ethanol solvent in a ratio of 1:3 was done. The extraction was done by maceration method for three hours at room temperature while stirring every 15-20 minutes, then it was filtered. The results of the filter were evaporated using a vacuum evaporator to produce ethanol extracts of cocoa beans. ${ }^{6}$

The extracts were tested for the total phenolic content measured by the Folin-Ciocalteu method. ${ }^{7}$ The extract of $253.4 \mathrm{mg}$ was dissolved with acetone: water (7:3). Then, the volume of up to $50 \mathrm{ml}$ was adequate into a flask. $1 \mathrm{ml}$ of sample solution was pipetted and put into a $50 \mathrm{ml}$ flask and $20 \mathrm{ml}$ of distilled water was added. A total of $2 \mathrm{ml}$ of Folin-Ciocalteu reagent was added to the flask and left for 5 minutes. After that, $20 \mathrm{ml}$ of $7 \%$ sodium carbonate were added to the mixture, and the volume was made to 50 $\mathrm{ml}$ with distilled water. The mixture was left for 90 minutes. The absorbance of the mixture was measured at $750 \mathrm{~nm}$ using a spectrophotometer. Standard curves were made using various concentrations of tannic acid. The results were expressed as percent tannic acid. $^{8}$

The flavonoid content of the cocoa bean extract was determined by the aluminum chloride colorimetric assay method. ${ }^{7}$ An extract of $251.1 \mathrm{mg}$ was dissolved with methanol as a solvent. The volume was up to $50 \mathrm{ml}$ in a flask. An amount of $0.5 \mathrm{ml}$ of the sample solution was pipetted and put in a $50 \mathrm{ml}$ flask and then $20 \mathrm{ml}$ of distilled water was added. 1.5 $\mathrm{ml}$ of $5 \% \mathrm{NaNO} 2$ was left for 5 minutes. After $5 \mathrm{mi}-$ nutes, $10 \mathrm{ml}$ of $\mathrm{AlCl} 310 \%$ was added to make a volume of $50 \mathrm{ml}$ with distilled water. The absorbance of the solution was measured at $510 \mathrm{~nm}$. The standard curves are made using various concentrations of catechins. The results were expressed as percent catechins. 
At the beginning of the seventh week, the experimental animals in the $\mathrm{k} 3$ group were given extracts at a dose of $4 \mathrm{mg} / 30 \mathrm{gBB} / \mathrm{po} / \mathrm{hrby}$ using gastric sonde. The extract was administered for up to 4 weeks.

At the beginning of the 11th week, the right cheek mucosal tissue was taken by biopsy. Previously, the mice were anesthetized with ether, and then the mice were sacrificed. Biopsy tissue has been put into formalin and used as an IFN $\gamma$ level examination by the immunohistochemical method.

The data obtained were presented descriptively, and the normality, homogeneity, and difference tests were carried out. Data analysis was performed with a computer program, the SPSS version 21.

\section{RESULT}

At the beginning of the 11th week, mice were biopsied and sacrificed. The results of measuring IFN $\gamma$ expression can be seen in Table 1.

Table 1. Mean and standard deviation (SD) of the IFNy expression

\begin{tabular}{|l|c|c|}
\hline Group & $\mathrm{n}$ & $\begin{array}{c}\mathrm{IFN} \gamma\left(/ 625 \mu^{2}\right) \\
(\mathrm{mean} \pm \mathrm{SD})\end{array}$ \\
\hline K0 & 4 & $1.200 \pm 0.135$ \\
\hline K1 & 4 & $1.025 \pm 0.125$ \\
\hline K2 & 4 & $3.750 \pm 1.452$ \\
\hline
\end{tabular}

Based on the results of the normality test with the Shapiro-Wilk test, the amount of IFN $\gamma$ expressions was normally distributed. Homogeneity test with the Levene test shows that the data was not homogeneous; therefore, a nonparametric statistical test was performed with the Kruskal-Wallis test to determine differences in all groups. The results showed that there was a significant difference in at least one group with $p=0.004(<0.05)$, followed by the MannWhitney test to see which groups were different. The results can be seen in Table 2 .

Based on Table 2, there was a significant difference between $\mathrm{K} 0$ group with $\mathrm{K} 2$ group, and $\mathrm{K} 1$ group with $\mathrm{K} 2$ group.

Table 2. The Mann-Whitney test results on the amount of IFN $\gamma$ expressions

\begin{tabular}{|l|l|l|l|}
\hline & K0 & K1 & K2 \\
\hline K0 & - & 0.557 & $0.020^{*}$ \\
\hline K1 & & & $0.021^{*}$ \\
\hline K2 & & & \\
\hline
\end{tabular}

*:significant

\section{DISCUSSION}

The increase in the prevalence of cancer including Oral Squamous Cell Caarcinoma (OSCC), is inseparable from the poor lifestyle of the community, among others due to smoking. Several things can cause cancer risk, but smoking is said to be the riskiest material to cause OSCC. ${ }^{9}$ This happens because cigarettes contain carcinogenic benzopyrene. ${ }^{10}$ Benzopyrene is also present in motorcycle exhaust fumes and smoked or baked foods. ${ }^{11}$ Therefore, in this stu$\mathrm{dy}$, the creation of a model of mice undergoing cell transformation was done by the induction of benzopyrene.

In addition, the modelling of mice undergoing cell transformation in this study was carried out by administering benzopyrene injection, which was a polycyclic aromatic hydrocarbon compound that had mutagenic and highly carcinogenic effects so that it was widely investigated. ${ }^{12}$ This compound can enter the body through the mouth, nose, and skin.

The results showed that the groups that were given ethanol extract of cocoa beans (K2) expressed a significantly higher amount of IFN $\gamma$ compared to the normal control group (K0) and negative control (K1). This means that the ethanol extract of cocoa beans can increase IFN $\gamma$ expression.

This happens because the ethanol extract of cocoa beans with their flavonoid content (catechin, proanthocyanidin, and anthocyanidin) is thought to increase IFN $\gamma$ expression through the increase in macrophage cell activity through the activation of $I K B$ Kinase (IKK) resulting in inactivation of IK $\beta$. This causes $N F k \beta$ which was originally bound to IK $\beta$ to be active and translocated into the cell nuc-leus. ${ }^{13,14}$ This increases the activation of $\mathrm{NFk} \beta$ responsive genes, which then increases cytokine production. ${ }^{15} \mathrm{In}$ this case, it causes an increase in IL-1 andIFN $\gamma$ cytokines. IL-1 activates Th and proliferates into Th1 /CD4 cells that produce IFN $\gamma$.

In this study, the normal control group also showed a small amount of IFNyexpression. This is possible because physiologically macrophages are also active in mice. In addition, at the time of the study, it was difficult to find sterile oral cavity of the mice.

Based on the study results, it can be concluded that the ethanol extract of cocoa beans can increase IFN $\gamma$ expression in Balb/c mice undergoing cell transformation. 


\section{REFERENCES}

1. Kementerian Kesehatan RI. Riset kesehatan dasar (RISKESDAS), Jakarta: Badan Litbang Kemenkes RI.2013: 5

2. Tanaka T, Tanaka M, Tanaka TH. Oral carcinogenesis and oral cancer chemoprevention: a review. Pathol Research Int 2011; 431246: 1-10

3. Thangapazham RL, Sharma A, maheshwari RK Multiple molecular targets in cancer chemoprevention by curcumin. AAPS J 2008; 8: 443-447

4. Rusconi M, Conti A. Theobroma cacao L, the Food of the Gods: A scientific approach beyond myths and claims. J Phar Res 2010; 61:5-13

5. Abbas AK, Lichtman AH, Pillai S. Cellular and molecular immunology. $8^{\text {th }}$ ed.Saunders, 2011: 267320

6. Departemen Kesehatan Republik Indonesia. Farmakope Indonesia. Edisi V. Jakarta, 2014: 7.

7. Uribe CK, Bektash RM. Cocoa flavanols: measurement, bioavailability and bioactivity. Asia Pac J Clin Nutr2008;17(S1):280-283

8. Lee, K.W., Kim,Y.J., Lee, H.J., dan Lee, C.Y. Cocoa has more phenolic phytochemical and higher antioxidant capacity than teas and red wine. J.Agric. Food. Chem.2003; 51:7292 - 7295

9. Matiasovic, J ,Maskova.L, Kummer. V, Faldyna. M. Effects of postnatal exposure to benzo[a]pyrene on the immunity on immature rats, Veterinarni Medicina 2008; 53(2): 93-100

10. Publik Health England. Polycyclic aromatic hydrocarbons (Benzo[a]pyrene) toxicological overview. Toxicology Department CRCE, PHE 2008: 1-10

11. GuoN, Faller DV, Vaziri C. Carcinogen Induced Sphase arrest is Chk 1 mediated and caffeine sensitive. Cell Growth Differentiation 2012; 13: 77-86

12. Corthay A. Does the immune system naturally protect against cancer? J Frontier in Immunol 2014;5: 197

13. Wang Z, Wesche H, stevevs T, Walker N, Yeh WC. IRAK -4 inhibitors for inflammation. Curr Top Med Chem 2009; 9: 724-37.

14. Yao K, Zhang L, Zhang YD, Ye P, Zhu N. The flavonoid, fisetin, inhibits UV radiation-induced oxidative stress and the activation of NF-KB and MAPK signaling in human lens epithelial cells. Molecular Vision 2008; 14: 1865-71.

15. NirwanaI ,Agustantina TH , Soekartono RH. Nf-Kb Expressions on rat dental pulp Mechanically Exposured after Pomegranate Fruit Extract Administration. J. Int Dent and Med Res, 2017;10(1): 123-7 